\title{
PENGARUH LAYANAN BIMBINGAN KELOMPOK DENGAN METODE TIME TOKEN ARENDS UNTUK MENINGKATKAN KETERAMPILAN SOSIAL MAHASISWA
}

\author{
Afrilia Safitri, Yessy Elita \\ Prodi Bimbingan dan Konseling Fakultas Keguruan dan Ilmu Pendidikan \\ Universitas Bengkulu \\ Apriliaa309@gmail.com, yessyelita@unib.ac.id
}

\begin{abstract}
ABSTRAK
Penelitian ini bertujuan untuk mendeskripsikan pengaruh layanan bimbingan kelompokdengan menggunakan metode time token arends untuk meningkatkan keterampilan sosial mahasiswa Himpunan Mahasiswa Bengkulu Utara. Metode yang digunakan adalah metode Quasi Experiment dengan desain one group pre test and post test. Sampel dalam penelitian ini adalah siswa mahasiswa Himpunan Mahasiswa Bengkulu berjumlah 12 orang. Prosedur pengambilan sampel menggunakan purposive sampling. Teknik pengumpulan data menggunakan angket dengan skala model Likert. Teknik analisis data menggunakan uji t. Hasil penelitian menunjukan bahwa tingkatketerampilan sosial mahasiswa sebelum diberikan layanan rata-rata skor 178,33 dengan kategori sedang. Nilai setelah diberikan layanan ratarata skor 256,42dengan kategori tinggi. Hasil uji t menunjukan nilai $t=(-9,219)$ danp $=0.000$ maka $\mathrm{p}<0.05$, sehingga hipotesis $\mathrm{H}_{0}$ ditolak dan $\mathrm{H}_{\mathrm{a}}$ diterima. Artinya ada pengaruh yang signifikan terhadap peningkatan keterampilan sosial sebelum dan setelah diberi layananbimbingan kelompok dengan metode time token arends.
\end{abstract}

Kata kunci : keterampilan sosial, layanan bimbingan kelompok, metode time token arends

\section{EFFECT OF GRUP GUIDANCE SERVICES WITH TIME TOKEN METHOD TO IMPROF THE SOCIAL SKILLS OF STUDENTS}

\begin{abstract}
The purpose of this research was to describe the effect of grup guidance services withtime token method to upgrade the social skills of students Himpunan Mahasiswa Bengkulu Utara . This research was used Quasi experimental research method with one group pre-test and post-test research design. The sample of this research was students from Himpunan Mahasiswa Bengkulu Utara total 12 student. The technique of collecting data of this research was used questionnaires with Likert scale models. The technique of analysis data of this research was used t test. The results showed that students social skills before the service given an average score of 178,3in the medium category. Value after the service given an average score of 256,42 with a high category. The result of t test was as big as $-9,219$ and shows zig mark. (2-tailed) as big as $0{ }^{\prime} 000<0,05$. So, hypothesis $\left(\mathrm{H}_{0}\right)$ refused and $\left(\mathrm{H}_{\mathrm{a}}\right)$ accepted, so that, it can be conclude that there are the effect of grup guidance services withtime token method to upgrade the social skills of students Himpunan Mahasiswa Bengkulu Utara.
\end{abstract}

Keywords : grup guidance services, social skills, time token method 


\section{Pendahuluan}

Setiap orang membutuhkan keterampilan sosial. Individu dengan keterampilan sosial akan mampu mengungkapkan perasaan baik positif maupun negatif dalam hubungan interpersonal, tanpa harus melukai orang lain (Yusranadam, dalam Maharani dkk,2018: 66). Keterampilan sosial merupakan aspek yang sangat penting dalam proses penyesuaian diri remaja, agar bisa berkembang menjadi individu dengan pribadi yang sehat. Hal ini perlu diperhatikan mengingat masa remaja dapat dikatakan sebagai masa yang paling sulit dan masa yang rawan dalam tugas perkembangan manusia ini karena masa remaja adalah masa pancaroba atau masa transisi, dan masa kanak-kanak menuju ke masa dewasa.

Amtorunajah \& Masruri (2015: 3), mengatakan bahwa keterampilan sosial adalah suatu kemampuan yang dimiliki seseorang untuk mampu bergaul, bekerja sama dengan orang lain baik individu maupun kelompok sehingga terjalin ikatan nonfisik dalam masyarakat di mana ia berada. Oleh karena itu, keterampilan sosial sangat dibutuhkan mahasiswa sebagai pondasi dalam berinteraksi di lingkungan kampus terutama di dalam proses berorganisasi. Puspintari (2017: 163), menjelaskan bahwa perkembangan sosial yang berkaitan dengan keterampilan sosial dalam dapat dimaknai dengan melaksanakan kegiatan berkelompok dan pemberian tugas kelompok, baik yang membutuhkan fisik maupun pikiran.

Menurut Prayitno dan Amti (2004 : 309), bimbingan kelompok merupakan layanan bimbingan yang diberikan dalam suasana kelompok. Melalui layanan bimbingan kelompok keterampilan sosial mahasiswa dapat terbina dan berkembang. Ditambah dengan menggunakan metode Time Token Arends yang dapat meningkatkan keaktifan mahasiswa dengan metode yang mudah serta inovatif digunakan dalam proses diskusi.

Model Time Token Arends merupakan salah satu metode yang melibatkan mahasiswa secara keseluruhan secara aktif, karena menurut Kurniasih dan Sani (2016: 107), model pembelajaran ini merupakan model pembelajaran demokratis serta mahasiswa dapat dibentuk dalam kelompok belajar. Selain itu model pembelajaran juga sangat tepat untuk pembelajaran yang telah terencana dan digunakan untuk melatih kemampuan berbicara mahasiswa (Widodo dalam Shoimin, 2014: 65). Metode ini dipilih oleh peneliti karena kegunaan metode ini yang dianggap dapat meningkatkan keterampilan sosial. Metode ini membuat mahasiswa mendapatkan kesempatan yang sama untuk mengutarakan sebuah pendapat atau memberikan kontribusi dalam menyampaikan pendapatnya serta menghargai pandangan atau pemikiran anggota lain, dengan menggunakan metode yang inovatif yang membuat mahasiswa semakin 
berlomba-lomba untuk mengeluarkan pendapatnya. Mahasiswa yang baik ialah mahasiswa yang tidak bersikap apatis atau acuh tak acuh terhadap suatu hal, mahasiswa dituntut agar dapat bersikap kritis terhadap banyak hal yang terjadi. Oleh karena itu dibutuhkan suatu wadah yang dapat menjadi tempat mahasiswa untuk dapat mengembangkan potensi serta inovasi yang dimilikinya. Robins dan Judge dalam (Wibowo, 2016: 1), organisasi adalah unit sosial yang secara sadar dikoordinasikan, terdiri dari 2 orang atau lebih yang berfungsi secara relatif berkelanjutan untuk mencapai tujuan bersama atau serangkaian tujuan. Organisasi HIMABU (Himpunan Mahasiswa Bengkulu Utara) merupakan salah satu organisasi yang dapat menjadi wadah bagi mahasiswa yang berasal dari Bengkulu Utara yang dapat mengembangkan potensi yang dimiliki anggotanya.

Hasil observasi yang dilakukan peneliti pada tanggal 11 Mei 2019 pada rapat yang dilakukan oleh anggota maupun pengurus HIMABU terlihat bahwa masih banyak mahasiswa yang memiliki keterampilan sosial yang rendah hal ini terlihat dari perilaku-perilaku anggota Himpunan Mahasiswa Bengkulu Utara seperti: tidak izin ketika meninggalkan rapat (kurang beretika), perilaku respon yang kurang baik, meninggalkan sampah disebarang tempat, kurang aktif dalam bertanya dan menjawab pertanyaan, kurang percaya diri untuk lebih menunjukan diri dalam organisasi, tidak dapat menerima pendapat orang lain, kurang perhatian antar sesama anggota, dan belum bisa memanajemenkan waktu untuk berorganisasi serta mereka terkadang susah atau masih malu-malu untuk memulai pembicaraan bahkan untuk rekan disampingnya.

Melihat dari fenomena yang telah diuraikan maka penulis tertarik untuk meneliti hal tersebut dan mengambil judul "Pengaruh Layanan Bimbingan Kelompok dengan Menggunakan Metode Time Token Arends untuk Meningkatkan Keterampilan sosial Mahasiswa Himpunan Mahasiswa Bengkulu Utara (HIMABU)".

\section{Metode Penelitian}

Metode yang digunakan dalam penelitian ini adalah metode pre-experimental design dengan rancangan pre-test post-test one grup design. Penelitian ini digunakan untuk mengetahui adanya pengaruh suatu tindakan terhadap suatu variabel. Variabel yang digunakan untuk memprediksi disebut variabel prediktor atau variabel bebas (independent). Variabel yang diprediksi disebut variabel kriterium/criteria atau variabel terikat (dependent). Teknik pengambilan sampel ini dengan menggunakan cara purposive sampling Teknik 
purposive sampling adalah teknik penentuan sampel dengan pertimbangan tertentu (Sugiyono, 2015:124).

Sampel pada penelitian ini pada mahasiswa HIMABU (Himpunan Mahasiswa Bengkulu Utara). Teknik Pengumpulan data dalam penelitian ini adalah menggunakan kuesioner (angket) yang disebarkan melalui google form dengan menggunakan model skala likert dengan kriteria dan alternatif jawaban (SS)Sangat Sesuai, (S) Sesuai, (TS)Tidak Sesuai dan (STS) Sangat Tidak Sesuai. Angket ini digunakan untuk mengukur tingkat keterampilan sosial mahasiswa HIMABU (Himpunan Mahasiswa Bengkulu Utara).

Dalam penelitian ini syarat uji daya beda yang digunakan adalah $>0,30$ jika dibawah 0,30 maka item tersebut dinyatakan gugur. Dari 88 angket yang disebarkan sebanyak 31 item angket gugur dan menyisakan 57item angket valid. Apabila instrumen sudah dinyatakan valid, maka angket tersebut akan digunakan sebagai alat ukur untuk mengukur tingkat keterampilan sosial mahasiswa HIMABU (Himpunan Mahasiswa Bengkulu Utara). Uji validitas instrumen merupakan prosedur pengujian untuk melihat apakah pernyataan yang digunakan dalam kuesioner dapat mengukur dengan cermat atau tidak dengan menggunakan bantuan SPSS 17.

\section{Tabel 1}

\section{Reliabilitas Angket Keterampilan sosial}

\begin{tabular}{lll}
\hline Cronbach's Alpha & $\begin{array}{l}\text { Cronbach's Alpha Based on } \\
\text { Standardized Items }\end{array}$ & No of Items \\
\hline 0,934 & 0,949 & 57 \\
\hline
\end{tabular}

Untuk memperoleh reliabilitas suatu instrumen maka dalam penelitian ini menggunakanan rumus Alpha Croanbach's dengan bantuan aplikasi computer software Statistical Packages for Sosial Sience (SPSS) versi 17 for windows. Berdasarkan tabel 1 didapati alpha cronbach senilai 0,934yang artinya lebih besar dari 0,949 maka artinya hasil tersebut dapat dikatakan reliabel dengan nilai yang.

\section{Hasil dan Pembahasan}

Deskripsi data yang disajikan dalam penelitian ini adalah dengan deskripsi data dari tingkat keterampilan sosial mahasiswa sebelum, sesudah dan cara layanan bimbingan kelompok dengan metode Time Token Arends untuk keterampilan sosial mahasiswa. Kuesioner keterampilan sosial yang terdiri dari 57 item dengan 5 pilihan jawaban yang bergerak dari 1-5, sehingga diperoleh rentang minimum adalah $57 \times 1=57$ maximum adalah 
$57 \times 5=285$, sehingga luas jarak sebarannya adalah $285-57=228$. Dengan demikian setiap satuan deviasi standarnya bernilai $=228 / 6=38$ dan mean idealnya adalah 171 . Pemberian pretest pada tanggal 24Juni 2019 dengan jumlah responden 33 orang siswa diperoleh hasil :

Tabel 2

\section{Hasil Pre-Test keterampilan sosial Mahasiswa}

\begin{tabular}{ccc}
\hline Kategori & Frekuensi & Persentase \\
\hline Sangat Tinggi $(>272)$ & 0 & 0 \\
\hline Tinggi $(220-271)$ & 4 & 12,12 \\
\hline Sedang $(168-219)$ & 24 & 75,75 \\
\hline Rendah $(116-167)$ & 4 & 12,12 \\
\hline Sangat Rendah $(<115)$ & 0 & 0 \\
\hline Total & $\mathbf{3 3}$ & $\mathbf{1 0 0}$
\end{tabular}

Berdasarkan tabel 2 diketahui bahwa keterampilan sosial mahasiswa HimpunanMahasiswa Bengkulu Utara tergolong rendah. Seperti ditunjukkan tidak terdapat mahasiswa yang memiliki keterampilan sosial sangat tinggi. Mahasiswa dalam kategori memiliki keterampilan sosial sedang dengan skor (168-219) berjumlah 5 orang dengan persentase sebesar 41,67\%. Mahasiswa dalam kategori memiliki tingkat keterampilan sosial rendah dengan skor (116-167) berjumlah 7 orang dengan persentase sebesar 58,33\%. Dapat disimpulkan bahwa mahasiswa himpunan mahasiswa Bengkulu Utara memiliki tingkat keterampilan sosial pada level sedang-rendah sebelum diberikan treatment layanan bimbingan kelompok dengan menggunakan metode time token arends.

Cartledge \& Milburn (Dewi,2013:16-17) mengemukakan bahwa aspek keterampilan sosial: 1) Perilaku diri, aspek ini berkaitan dengan perilaku diri seorang individu seperti menerima konsekuensi, perilaku etika, mengekspresikan perasaan, perilaku respon, perduli terhadap diri sendiri, 2) Perilaku lingkungan meliputi : peduli lingkungan, peka dengan keadaan darurat, 3) Perilaku terkait tugas meliputi : bertanya dan menjawab pertanyaan, memperhatiakn penjelasan, diskusi kelas, menyelesaikan tugas-tugas, mengikuti arah/ peraturan, kegiatan kelompok, mengerjakan tugas, menunjukkan diri, dan 4)Perilaku interpersonal meliputi: mengatasi konflik, menunjukan perhatian, mengucapkan salam, membantu orang lain, membuat percakapan, berorganisasi, mampu menerima, orang lain apa adanya, mengatur diri. Pendapat dari Cartledge \& Milburn(Dewi,2013:16-17) ini selaras dengan kondisi yang dialami mahasiswa sebelum treatment. Sebelum treatment diberikan masih banyak mahasiswa yang memiliki keterampilan sosial yang rendah, sehingga beberapa dari mahasiswa saat bimbingan kelompok berlangsung masih cenderung ragu-ragu untuk 
mengeluarkan pendapat serta saran. Akan tetapi seiring berjalannya waktu mereka mulai mengerti arah dari diskusi yang dibahas mengenai materi keterampilan sosial.

Jadi, dapat disimpulkan bahwa keterampilan sosial yang rendah terjadi akibat kurangnya pemahaman akan pentingnya keterampilan sosial serta ketidak pedulian untuk memahami pentingnya keterampilan sosial.

Setelah pengujian dilakukan peneliti memberikan treatment selama 6 kali, dengan treatment yang diberikan adalah layanan Bimbingan Kelompok dengan menggunakan Metode Time Token Arends. Menurut Prayitno (1995;61), Layanan bimbingan kelompok adalah suatu layanan bimbingan yang diberikan kepada mahasiswa secara bersama-sama atau kelompok agar kelompok itu menjadi besar,kuat dan mandiri. Layanan ini diberikan secara tatap muka atau langsung dengan tujuan agar layanan yang diberikan dapat lebih efektif dalam pelaksanaannya.Kegiatan layanan yang dilakukan sebanyak 6 pertemuan pada mahasiswa himpunan mahasiswa Bengkulu Utara yang memiliki skor pre-test terendah sebanyak12 orang mahasiswa

Selama 6 kali pertemuan yang sudah dilakukan dengan alokasi waktu sekitar 60 menit, anggota kelompok semakin akrab dan terbuka untuk berbagi mengenai saran, pengalaman dan informasi sehingga terjadi peningkatan keterampilan sosial yang cukup signifikan. Berbeda dengan pertemuan yang pertama dan kedua, mahasiswa masih malu-malu dan raguragu untuk mengeluarkan pendapatnya.

Pada pertemuan pertama topik yang dibahas adalah materi berperilaku sesuai etika, pertemuan kedua membahas topik mengenai peduli terhadap diri sendiri. Pertemuan ketiga membahas membahas topik mengenai peduli tarhadap lingkungan, pertemuan keempatmembahas topik mengenai menunjukkan diri. Pertemuan kelima membahas topik mengenai membantu orang, pertemuan terakhirmembahas topik mengenai.

Pada saat mengisi post-test, mahasiswa sudah lebih memahami diri sendiri, bagaimana menjadi pribadi yang baik dan mulai meningkat keterampilan sosialnya. Terlihat dari hasil post-test skala keterampilan sosial Mahasiswa Himpunan Mahasiswa Bengkulu Utara setelah diberikan treatment berupa layanan bimbingan kelompok dengan menggunakan metode time token arends menunjukkan tingkat keterampilan sosial mahasiswa mengalami peningkatan.

Pengukuran tingkat keterampilan sosialsetelah pemberian treatment dengan layanan Bimbingan Kelompok dengan menggunakan Metode Time Token Arendsdilakukan dengan 
pemberian post-test kepada 12 orang mahasiswa yang menjadi sampel penelitian yang dilaksanakan pada tanggal 12 Juli 2019 mendapatkan hasil :

Tabel 3

Perbandingan Skor Pre-test dan Post-test Keterampilan Sosial

\begin{tabular}{lccccc}
\hline SUBJEK & \multicolumn{5}{c}{ HASIL } \\
\cline { 2 - 6 } & $\begin{array}{c}\boldsymbol{P R E} \text { - } \\
\text { TEST }\end{array}$ & KATEGORI & $\begin{array}{c}\text { POST- } \\
\text { KEST }\end{array}$ & KATEGORI & KENAIKAN \\
\hline SC & 142 & Sedang & 228 & Tinggi & 86 \\
\hline FN & 148 & Rendah & 231 & Tinggi & 83 \\
\hline SP & 149 & Rendah & 227 & Tinggi & 78 \\
\hline EW & 140 & Sedang & 195 & Sedang & 55 \\
\hline PR & 159 & Sedang & 205 & Tinggi & 46 \\
\hline RI & 145 & Rendah & 260 & Sangat tinggi & 115 \\
\hline RA & 177 & Sedang & 254 & Tinggi & 77 \\
\hline An & 146 & Rendah & 223 & Tinggi & 77 \\
\hline MW & 173 & Sedang & 197 & Tinggi & 24 \\
\hline AM & 172 & Sedang & 221 & Tinggi & 49 \\
\hline FA & 173 & Sedang & 269 & Sangat tinggi & 96 \\
\hline DI & 148 & Sedang & 227 & Tinggi & 79 \\
\hline TOTAL & 1872 & & 2737 & & $\mathbf{8 6 5}$ \\
\hline MAX & 177 & & 269 & \\
\hline MIN & 140 & & 195 & \\
\hline MEAN & 156,00 & & 228,08 & \\
\hline STDEV & 13,93 & & 23,44 \\
\hline
\end{tabular}

Tabel 3 menunjukkan perbedaan skor dan mean pre-test dan post-test tingkat keterampilan sosial, yang diketahui pada skor pre-test sebanyak 7 orang mahasiswa (SC, FN, SP, EW, RI, AN, DI) memiliki tingkat keterampilan sosial yang rendah dan 5 mahasiswa lainnya (PR, RA, MW, AM, FA) berkategori sedang, dengan rata-rata (mean) sebesar 156. Kemudian setelah diberikan treatment, skor hasil post-test didapatkan 2 mahasiswa (FA dan RI) memiliki tingkat keterampilan sosial pada kategori sangat tinggi, 9 mahasiswa (SC, SN, SP, PR, RA, AN, MW, AM DI)memiliki tingkat keterampilan sosial pada kategori tinggi dan 1 mahasiswa lainnya (EW) berada pada kategori sedang, dengan rata-rata keterampilan sosial sebesar 228,08.

Kriteria penerimaan atau penolakan hipotesis adalah jika nilai Sig. $(2-$ tailed $)<0,05$ maka Ho ditolak, namun jika nilai Sig. $(2$ tailed) > 0,05 maka Ho diterima . Berdasarkan hipotesis dalam hasil yang diperoleh dengan menggunakan bantuan (SPSS 17.0), dengan uji Paired sample t test adalah sebagai berikut : 


\section{Tabel 4}

\section{Hasil Uji t}

\begin{tabular}{ccc}
\hline & T & Sig. \\
\hline Pre-test, Post-test & -10.137 & .000 \\
\hline
\end{tabular}

Berdasarkan Tabel 4 dapat dijelaskan bahwa Sig. ( 2 tailed) sebesar 0.000 yang artinya nilai Sig.(2 tailed) lebih kecil dari 0.005 maka hipotesis (Ho) ditolak dan hipotesis (Ha) diterima. Dapat disimpulkan bahwa ada peningkatan keterampilan sosial mahasiswa Himpunan Mahasiswa Bengkulu Utarasetelah diberikan treatment berupa layanan bimbingan kelompok dengan menggunakan metode time token arends.Perubahan tingkat keterampilan sosial mahasiswa pada pre-test dan post-test melalui uji Paired sample $t$ test menunjukkan hasil -10.137 dengan signifikansi $.000(\mathrm{p}<0,05)$ yang berdasarkan kriteria penerimaan atau penolakan hipotesis Ho ditolak dan Ha diterima.

Berdasarkan hasil Uji t menyimpulkan bahwa adanya pengaruh bimbingan kelompok dengan menggunakan metode time token arends terhadap tingkat keterampilan sosial pada Mahasiswa Himpunan Mahasiswa Bengkulu Utara. Keterampilan sosial adalah perilaku untuk menyesuaikan diri dimanapun berada dan ditempatkan serta cara kita agar dapat diterima oleh lingkungan. Jika keterampilan sosial mahasiswa rendah tentunya mengganggu sistem berorganisasimahasiswa yang mengharuskan mahasiswa untuk selalu aktif berpendapat dan mengemukakan pikiran yang dimilikinya.

Peningkatan keterampilan sosial tidak terlepas dari peran para anggota kelompok itu sendiri dimana anggota kelompok saling memotivasi, memberikan semangat, pendapat dan ide-ide serta mau melibatkan diri pada kondisi kelompok sehingga manfaat pemberian treatment atau layanan bimbingan kelompok pun dapat dirasakan. Menurut Prayitno (1995:178) bahwa bimbingan kelompok adalah suatu kegiatan yang dilakukan oleh sekelompok orang dengan memanfaatkan dinamika kelompok.

Adanya layanan bimbingan kelompok dengan menggunakan metode time token arends ini dapat membuat mahasiswa sebagai anggota kelompok memperoleh banyak tujuan atau manfaat yang dirasakan sekaligus. Mahasiswa yang mempunyai tingkat keterampilan sosial yang rendah dapat mengembangkan pikiran, persepsi, perasaan, rasa, empati, wawasan, pengetahuan, meningkatkan sosialisasi dan berkomunikasi dan tentunya meningkatkan keterampilan sosial. 
Pelaksanaan bimbingan kelompok dengan menggunakan metode time token arends yang dilakukan peneliti juga menggunakan media time token cards. Modelpembelajarantime token arends sangat tepat untuk pemblajaran struktur yang dapat digunakan untuk mengajarkan keterampilan sosial,untuk menghindari mahasiswa mendominasi pembicaraan atau mahasiswa diam sama sekali.

\section{Kesimpulan}

Tingkat keterampilan sosial Mahasiswa Himpunan Mahasiswa Bengkulu Utara sebelum diberikan layanan bimbingan kelompok dengan menggunakan metode time token arends berada pada kategori sedang. Tingkat keterampilan sosial Mahasiswa Himpunan Mahasiswa Bengkulu Utara setelah diberikan layanan bimbingan kelompok dengan menggunakan metode time token arends mengalami peningkatan setelah diberikan treatment yaitu berada pada kategori tinggi.Terdapat pengaruh pemberian layanan bimbingan kelompok dengan menggunakan metode time token arends terhadap tingkat keterampilan sosial pada Mahasiswa Himpunan Mahasiswa Bengkulu Utara.

Bagi mahasiswa Himpunan Mahasiswa Bengkulu Utara yang menjadi sampel penelitian ini, dengan diberikannya pengetahuan, pemahaman, serta ilmu dan harus mempertahankan perilaku keterampilan sosial yang sudah dicapai. Bagi mahasiswa Prodi Bimbingan dan Konseling, diharapkan hasil penelitian ini dapat menambah ilmu pengetahuan dan dijadikan bahan pertimbangan dalam pemberian layanan bimbingan dan konseling untuk meningkatkan pelayanan bimbingan dan konseling ke depannya.Bagi peneliti selanjutnya, diharapkan hasil penelitian ini dapat dijadikan sebagai salah satu bahan acuan untuk mengembangkan penelitian lainnya yang berhubungan dengan variabel yang terkait dalam penelitian ini.

\section{Daftar Pustaka}

Amtorunajah \& Masruri, M. S. (2015). Peningkatan Keterampilan Sosial Siswa Dalam Pembelajaran IPS Melalui Outdoor Activity di SMP Negeri 1 Kaligondang Kabupaten Purbalingga. Harmoni Sosial: Jurnal Pendidikan IPS. 2 (1). Hal: 1-11.

Dewi,E.K.(2013).Peningkatan Keterampilan Sosial Melalui Bimbingan Kelompok Berbasis Cooperative Learning Di Smp Negeri 2 Pakem Kelas VIII C. Skripsi Universitas Negeri Yogyakarta

Kurniasih \& Sani. (2016). Ragam pengembangan model pembelajaran untuk Peningkatan Profesionalitas Guru. Surabaya: Kata Pena 
Laila,M., Hardiansyah,M., \& Miftahul,J.(2018)Peningkatan Keterampilan Sosial Peserta Didik SMA Menggunakan Layanan Bimbingan Kelompok Dengan Teknik Diskusi. Jurnal Bimbingan dan Konseling.05(1). Hal: 1-5

Prayitno \& Amti, E. (2004). Dasar-dasar Bimbingan dan Konseling. Jakarta: Rineka Cipta.

Prayitno. (1995). Layanan Bimbingan Dan Konseling Kelompok. Padang:Ghalia Indonesia

Puspintari, A. (2017). Pengaruh Penerapan Metode Inkuiri Terbimbing (Guided Inquiry) Terhadap Keterampilan Sosial Peserta Didik Pada Pembelajaran Tematik Integratif Kelas V di SD Negeri Jetis Bantul. Skripsi Universitas Negeri Yogyakarta

Shoimin, A. (2014). 68 Model pembelajaran inovatif dalam kurikulum 2013.Yogyakarta: ArRuzz Media

Sugiyono. (2013). Metode Penelitian Pendidikan. Bandung: Alfabeta. 451 hlmn.

Wibowo. (2016).Perilaku dalam Organisasi. Jakarta: Rajawali Pers. 318 hlmn. 